\title{
Mixed Siliciclastic-Skeletal Carbonate Lagoon Sediments from a High Volcanic Island, Viti Levu, Fiji, Southwest Pacific ${ }^{1}$
}

\author{
Oliver A. Gussmann and Abigail M. Smith ${ }^{2}$
}

\begin{abstract}
Modern sedimentation in the Navua-Suva Lagoon, southeastern Viti Levu, Fiji, derives from both allochthonous siliciclastics and autochthonous marine carbonates. Sediments are characterized by a high insoluble load, small grain size, a wide range of textures, and a high degree of mixing. The distribution of the two facies (skeletal-dominated muddy sandy gravel and skeletalbearing very fine sand to mud) is controlled by both the shallow-marine carbonate sediment productivity and sediment supply and dispersal processes from siliciclastic point sources across a narrow lagoon. Mollusks and Halimeda dominate the gravel fraction of the skeletal grains. Sediment budget estimates indicate that $97 \%$ of the siliciclastic supply bypasses the lagoon. Some $0.2 \mathrm{Mt} / \mathrm{yr}$ is accumulating in the lagoon, not yet enough to inhibit potential carbonate production $(\sim 0.1 \mathrm{Mt} / \mathrm{yr})$ by a interreefal benthos that is at least somewhat sediment-tolerant. Contemporary allochthonous siliciclastic and autochthonous skeletal carbonate sedimentation in the lagoon results in true syndepositional (in situ) mixing. The central high volcanic island mass in a tropical setting produces the geomorphological (high topographic relief, narrow shelf), environmental (high rainfall), and ecological (shallow benthic area) conditions that lead to carbonate-siliciclastic mixing in lagoons along adjacent, mostly carbonate, coasts of oceanic islands, a high volcanic island mass effect. We propose that tropical in situ mixing of carbonate and siliciclastic sediments is more common in high volcanic island settings than previously appreciated. Such islands are thus excellent testing grounds for the study of carbonate-siliciclastic interactions. Their special characteristics highlight the need for better understanding of coastal physical processes of tropical Pacific high volcanic islands.
\end{abstract}

High volcanic islands are common features of the tropical Pacific; they typically consist of a small, central island mass $\left(<\sim 10,000 \mathrm{~km}^{2}\right)$ of volcanic origin, with high relief ( $100 \mathrm{~s}$ to $>1000 \mathrm{~m})$, surrounded by

1 This study was supported and partly funded by the University of Otago; Mineral Resources Department, Fiji; The University of the South Pacific; and The South Pacific Applied Geoscience Commission, Fiji. The results of this paper were presented at the Ninth International Coral Reef Symposium, Bali, Indonesia, 23-27 October 2000, with financial assistance from the University of Otago and the New Zealand Marine Sciences Society. Manuscript accepted 6 September 2001.

2 University of Otago, Department of Marine Science, P.O. Box 56, Dunedin, New Zealand (E-mail: abbysmith@otago.ac.nz).

Pacific Science (2002), vol. 56, no. 2:169-189 (C) 2002 by University of Hawaici Press.

All rights reserved shallow-water coral reefs (Nunn 1994). Most high volcanic islands characterized by active tectonic settings lack wide, open shelves. Sediments eroded from the volcanic island mass should largely bypass the narrow lagoon-reef shelves (Milliman et al. 1999). Coastal sediments, therefore, are predicted to be dominated by the calcareous remains of coral reef organisms ("chlorozoan" assemblage of Lees and Buller [1972], phototrophic assemblages sensu James [1997]), as are atolls (Milliman 1974).

Pioneering work by Guilcher (1985) has shown that lagoonal sediments of several $\mathrm{Pa}$ cific (and Atlantic) high volcanic islands are derived from two sources: allochthonous terrigenous (volcani-)clastics and autochthonous marine (reefal and interreefal) skeletal carbonates. Such deposits are different from those of atolls formed entirely of calcium carbonate, 
but are not uncommon in tropical shallowwater continental shelf areas of modern and ancient equivalents (e.g., Doyle and Roberts 1988, Fay et al. 1992, D'Croz et al. 1998).

Siliciclastic sediments are generally thought to have adverse ecological effects on tropical, benthic carbonate-producing organisms (mostly corals) (e.g., Rogers 1990). Such organisms, therefore, should be excluded from areas with high terrigenous input. One long-held corollary was that skeletal carbonate sediments therefore could not mix with terrigenous sediments (e.g., Mount 1984). There is continued sedimentological interest (e.g., Larcombe and Woolfe 1999, Best and Kidwell 2000a,b, Heap et al. 2001) in, and increasing ecological and sociological concern (e.g., Baines and Morrison 1990, Bryant et al. 1998) about, the influence of siliciclastic sedimentation on carbonate production, sedimentation, and preservation (mostly of corals) along tropical coasts. However, very little has been documented on coastal sedimentology, sediment fluxes, and sediment dispersal on tropical Pacific high volcanic islands.

The purpose of this preliminary study was to explore the nature of lagoonal sedimentation within the tectonic, climatic, geomorphologic and oceanographic context of high volcanic islands. We focused on the modern sediments of the Navua-Suva Lagoon, situated in southeast Viti Levu (Fiii), a high volcanic island in the tropical Southwest Pacific (Figure 1). Surface sediment types were identified and mapped to illustrate the processes responsible for their deposition. The Navua-Suva Lagoon was also compared with other similar environments. Knowledge of the geometry, dynamics, and ecology of carbonate-siliciclastic mixtures may be a useful tool in predicting the impact of sediment runoff on carbonate production, particularly in Pacific Island societies, which rely heavily on coastal marine resources such as coral reefs and lagoons. These themes will be further explored in a future paper.

\section{Study Area}

REgional tectonic setTing: The islands of Fiji are situated at the northeastern corner of the Australian tectonic plate, about $800 \mathrm{~km}$ west of the Pacific Plate subduction zone into the Tonga Trench and about 3000 $\mathrm{km}$ east of Australia. Viti Levu (Figure 1), the largest island $\left(10,384 \mathrm{~km}^{2}\right)$ in the Fiji group, is formed largely from the accretion of islandarc complexes and associated sedimentary strata since the Eocene (Rodda 1994). Viti Levu is almost circular and rises rapidly from sea level to peaks as high as $1323 \mathrm{~m}$. The island's terrain is maturely dissected, with many Quaternary fluvial and littoral formations restricted to lowland valleys and coasts. The surrounding ocean is 2 to $4 \mathrm{~km}$ deep.

PRESENT-DAY LAGOON SETTING: The Navua-Suva Lagoon is located in southeastern Viti Levu between the township of Navua and the capital, Suva (Figure 1). The lagoon trends southwest for about $30 \mathrm{~km}$, reaching a maximum width of $4000 \mathrm{~m}$ in the southwest and a minimum width of $200 \mathrm{~m}$ in the northeast (Figure 1). Average water depth is $16 \mathrm{~m}$, ranging from the intertidal at the shore and on reef flats to $>80 \mathrm{~m}$ in reef passages (Gussmann 1996). Shoaling of the lagoon floor is evident in the southwest (Figure 1). Mangroves and extensive fringing reefs line most of the shores of the lagoon, allowing mud to accumulate. Sandy beaches are rare and confined to the vicinity of the Navua River, where they are mostly terrigenous. A number of patch reefs occur within the lagoon. A well-developed barrier reef system shelters the lagoon from most oceanic forces, but several reef passages ( 300 to $2000 \mathrm{~m}$ wide) connect the lagoon to the ocean (Figure 1). Oceanographic measurements in the lagoon (September-October 1994, dry season) show that the water is warm $\left(24.2-25.7^{\circ} \mathrm{C}\right)$ and saline $(34.7-35.2 \%$ ) at most depths (Gussmann 1996). Tides at nearby Suva (range, 0.9 to $1.3 \mathrm{~m}$ ) are semidiurnal with a dominant $M_{2}$ constituent.

The climate of southeastern Viti Levu is humid and tropical, with strong maritime influence. Mean monthly air temperatures at the coast range between 22 and $28^{\circ} \mathrm{C}$. Rainfall is characterized by high magnitude, seasonality, and short-term variability. Average annual coastal rainfall in southeastern Viti Levu is about $3 \mathrm{~m}$ with little interannual variation 


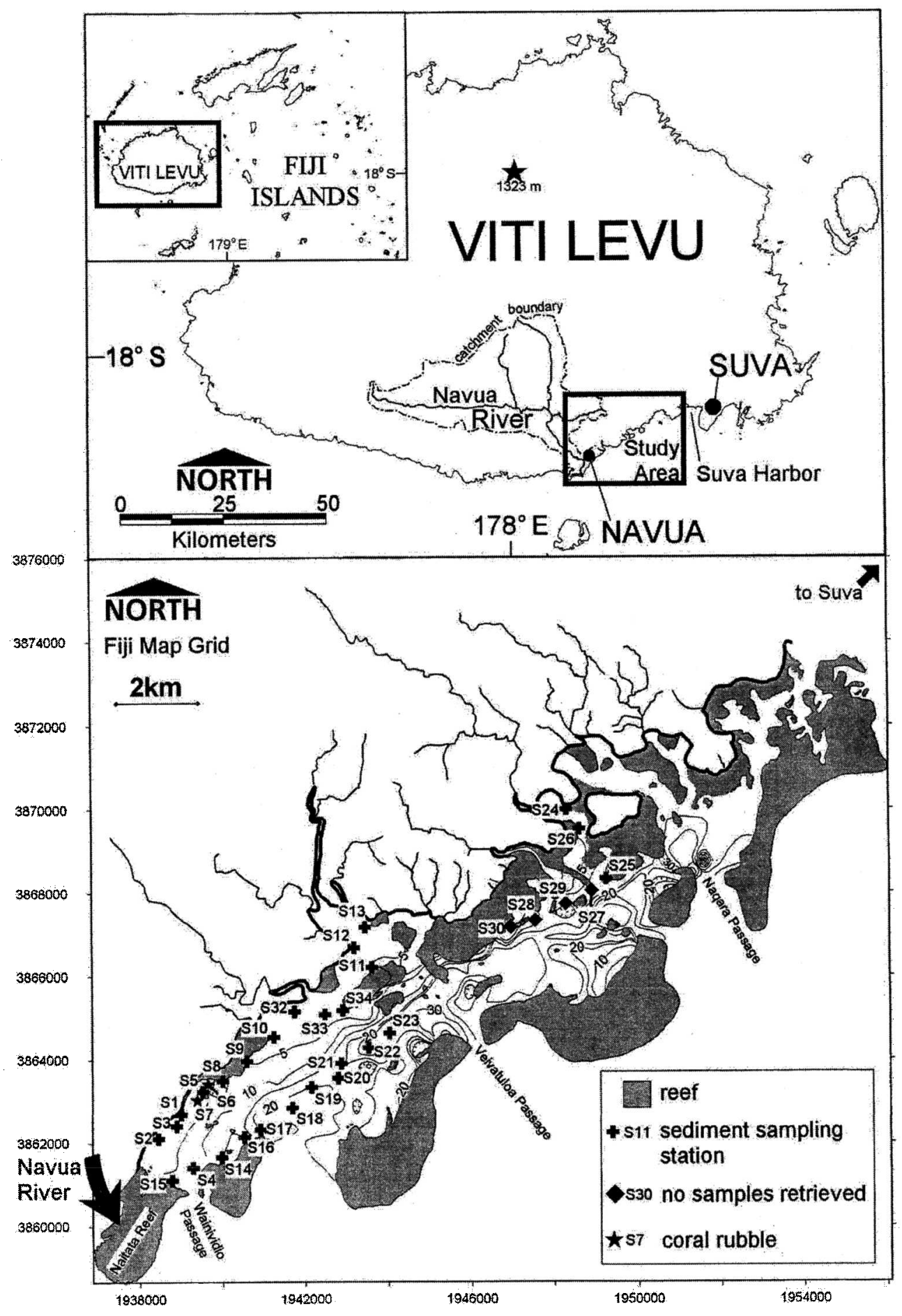

Figure 1. Location of the Navua-Suva Lagoon, Viti Levu, Fiji, showing the general depositional geomorphology. Major river and reef systems are indicated. Surface sample stations and names referred to in text are also shown. Diamonds show locations where no sediment was collected after repeated sampling. Stars denote samples composed of coarse coral rubble. Depth contours in 5-m intervals. Note that coordinate system in bottom inset is Fiji Map Grid. 
and can exceed $5 \mathrm{~m}$ in the central highlands due to orographic interception of the southeast trade winds, which dominate the wind pattern for most of the year. Mean monthly rainfall is $0.4 \mathrm{~m}$ from November to April and $0.2 \mathrm{~m}$ from May to October. Storms and cyclones introduce most of the short-term variability in rainfall (Howorth et al. 1981). For example, Harris (1980) reported that an area of approximately $1800 \mathrm{~km}^{2}$ within the upland Navua River catchment experienced a 2-day rainfall exceeding $0.5 \mathrm{~m}$, with $0.9 \mathrm{~m}$ falling at two stations over a $24-\mathrm{hr}$ period, during the passage of Cyclone Wally in 1980. Cyclones in Fiji occur at a rate of about one per year. Localized storms affect the study area virtually every year through heavy rain (Crozier et al. 1981).

Several rivers and streams drain into the lagoon, the most notable of which is the $\mathrm{Na}$ vua River (Figure 1), which discharges at the southwestern end of the lagoon. The Navua River has a drainage area of $1220 \mathrm{~km}^{2}$, a delta area of $50 \mathrm{~km}^{2}$, mean flow of $45 \mathrm{~m}^{3} \mathrm{sec}^{-1}$, and recorded peak flow of $6000 \mathrm{~m}^{3} \mathrm{sec}^{-1}$ following Cyclone Wally in 1980 (Derrick 1957, Harris 1980). The main river channel is shallow with depths ranging from 2 to $4 \mathrm{~m}$ (Smith and Saphore 1987). The headwaters of the Navua River are within the Navua Range, with peak elevations approaching $1000 \mathrm{~m}$ and rainfall as high as $5 \mathrm{~m} / \mathrm{yr}$. The extreme topography and rainfall decrease toward the coast, where rainfall averages about $3 \mathrm{~m} / \mathrm{yr}$ over a low-relief delta and low coastal hills. Tertiary volcanic and sedimentary rocks dominate the geology of the Navua River catchment area.

LATE QUATERNARY SEA-LEVEL HISTORY: Sea level in Fiji was about 120 to $150 \mathrm{~m}$ below present at the last glacial maximum around 18,000 yr ago (Nunn 1994). In southeastern Viti Levu, sea level rose steeply from $41 \mathrm{~m}$ depth around 9600 years ago to its current level 4500 to $4000 \mathrm{yr}$ ago as indicated by core dates from Suva Harbor (Figure 1) (Shorten 1993). A subsequent brief period of relative sea level highstand of no more than $0.6 \mathrm{~m}$ may have followed (Shepherd 1990, Shorten 1993).

\section{MATERIALS AND METHODS}

Twenty-seven surface sediment samples were collected over an approximate 1 by $1.5 \mathrm{~km}$ grid in the lagoon with a Van Veen-type grab sampler in 1994 (Figure 1). Textural analyses of samples included wet sieving into gravel, sand, and mud fractions and dry sieving of the sand fraction into 1- $\phi$ intervals. Statistical parameters (mean grain size, sorting, skewness, kurtosis) were calculated using the graphical method of Folk (1968) with the Rapid Sediment Analyser (RSA v 7.1) software developed at the University of Waikato (deLange et al. 1997). Relative contributions of noncarbonate (mostly siliciclastics, but also including authigenic minerals and organic matter in minor quantities) and carbonate (skeletal) material were determined by acid digestion of bulk samples. Sediment samples were classified as "mixed" when they contained more than $10 \%$ of the antithetic sediment type (sensu Mount 1985). Skeletal component composition by major taxa was determined for the gravel fractions to provide a preliminary indication of the important carbonate sediment contributors. The classification of biofacies is based on an ordered arithmetic binomial classification after Chevillon (1996) for comparative purposes. Sediment grain-size data and carbonate content were further analyzed by hierarchical clustering, using normalized Euclidean distance (shortest distance) and group average (average distance) algorithms with PRIMER v 4.0 (Clarke and Warwick 1994) as an additional aid in pattern recognition and process interpretation.

\section{RESULTS}

Textural analyses showed that Navua-Suva Lagoon surface sediments are characterized by a wide range of mixed carbonate-siliciclastic deposits (Table 1, Figures 2 and 3). Carbonate content ranged from 2 to $100 \%$ by weight (wt\%) (Table 1, Figure 2), with a mean of 38 wt $\%$ (standard deviation \pm 30 $w t \%)$. All but four samples were mixed, and only sample 25 is truly a carbonate sediment 
(>90 wt\% $\mathrm{CaCO}_{3}$ ) (Table 1). All but one (S5) of the samples were dominated by fine to very fine sand and mud fractions, which combined made up $71 \%$ of the total sand fraction (Table 1). Six samples had a gravel content of more than $10 \mathrm{wt} \%$ (Table 1, Figures 2 and 3). The most common modal and mean grain sizes were mud (50\% of samples) and very fine sand (39\% of samples) (Table $1)$. The majority of samples (74\%), therefore, were classified as mud or as having a muddy component (Table 1, Figure 3). Mean grain size, sorting coefficient, and skewness are all significantly correlated with carbonate content $\left(f_{(x)}=-3.2 x+4.0, R^{2}=4.9 ; f_{(x)}=\right.$ $1.2 x+7.2, R^{2}=4.6 ; f_{(x)}=3.6 x-2.1, R^{2}=$ 7.9 , respectively), suggesting that these parameters are related to sediment composition. Dominantly siliciclastic samples are well sorted, near symmetrical very fine sands to muds, whereas dominantly carbonate samples are coarse grained and poorly sorted; the latter are either strongly fine or coarse skewed and show greater variability in all parameters.

Two sediment facies are thus available to mix (Figures 4 and 5). Dominantly siliciclastic samples are characterized by finer grain size classes, which gradually fall out as carbonate content (mixing) increases, while coarse grain size classes increase (and vice versa, Figure 4). The samples in Figure 4, however, do not fall along a contiguous transect due to the comprehensive nature of mixing over the width of the lagoon (see Discussion), although gradients of mixing may be discernible with greater data density. Sorting deteriorates as mixing progresses (Figure 5).

Analysis of constituent components is based on the small gravel fraction only (Table 1), which may not be representative of the whole sample. It is used here for a preliminary analysis of the main carbonate formers contributing to the coarse fraction in the Navua-Suva Lagoon. Coral is only a minor component of sample gravel fractions (Figure 6). Dominant constituents, with decreasing rank, are mollusks (mainly bivalves), the calcareous green alga Halimeda, and Foraminifera (Figure 6). Coral was usually present in samples with high gravel and car- bonate contents, indicating that constituents influence sediment texture. Mollusks and Halimeda showed a weak inverse relationship ( $\left.y=48.6-0.7 x, r^{2}=0.42\right)$, suggesting local (patchy) contributions by one or the other dominant constituent. The mollusk-Halimeda biofacies imparts an overall interreefal imprint to the samples, with only local contributions from reefs. A relatively large component of the samples is made up of sub-rounded and smooth carbonate material whose source and age could not be identified (Figure 6).

Further analysis of sediment data (grain size fractions and $\mathrm{CaCO}_{3}$ content) by hierarchical clustering (Figure 7) was performed to aid in facies and process interpretation. Sample clusters were interpreted according to textural, compositional, and descriptive parameters and environmental affinities. The results are summarized in Table 2 and Figure 8.

Facies 1 (skeletal-dominated muddy sandy gravel) is dominated by medium to very coarse sandy to gravelly biogenic carbonates (Table 2). Bivalves and mostly whole or broken segments of Halimeda are the main suppliers of gravel-sized carbonate, which points to an interreefal rather than reefal source. All but one sample are mixed carbonate-siliciclastics, but the average siliciclastic content of facies $1(28 \mathrm{wt} \%)$ is significantly lower than in facies 2 sediments (Table 2). Facies 1 sediments are mostly poorly sorted carbonates, reflecting a combination of skeletal architecture and weak (or intermittent) hydraulic sorting on sediment texture. Minor addition of fine-grained sediment, which may be either carbonate or siliciclastic mud, under lowenergy conditions or by trapping, is implied by the fine to very fine skewed distributions. Facies 1 sediments are primarily controlled by benthic, interreefal carbonate production (Mollusca-Halimeda association in the gravel fraction), with local framework (coral, coralline algae) additions, deposited in a lowenergy environment, that determine its texture and composition. Dilution by siliciclastics is less important.

Facies 2 (skeletal-bearing very fine sand to mud) sediments are dominated by the non- 
TABLE 1

Sampling Data and Results of Textural and Compositional Analyses of Navua-Suva Lagoon Surface Sediment Samples

\begin{tabular}{|c|c|c|c|c|c|c|c|c|c|c|c|c|c|}
\hline $\begin{array}{l}\text { Sample } \\
\text { No. }\end{array}$ & $\begin{array}{l}\text { Date } \\
\text { Collected } \\
(1994)\end{array}$ & $\begin{array}{l}\text { Longitude } \\
\text { (E) }\end{array}$ & $\begin{array}{l}\text { Latitude } \\
\text { (S) }\end{array}$ & $\begin{array}{l}\text { Depth } \\
\text { (m) }\end{array}$ & $\begin{array}{c}\mathrm{CaCO}_{3} \\
(\mathrm{wt} \%)\end{array}$ & $\begin{array}{l}\text { Gravel } \\
\text { (wt\%) }\end{array}$ & $\begin{array}{c}\text { Sand } \\
\text { (wt\%) }\end{array}$ & $\mathrm{vcs}^{a}$ & cs & $\mathrm{ms}$ & fs & vfs & $\begin{array}{l}\text { Mud } \\
\text { (wt\%) }\end{array}$ \\
\hline 1 & 3 June & $178^{\circ} 10^{\prime} 14^{\prime \prime}$ & $18^{\circ} 14^{\prime} 21^{\prime \prime}$ & 3 & 11 & 0 & 45 & 0 & 0 & 1 & 17 & 26 & 55 \\
\hline 2 & 3 June & $178^{\circ} 10^{\prime} 07^{\prime \prime}$ & $18^{\circ} 14^{\prime} 43^{\prime \prime}$ & 3 & 10 & 0 & 46 & 0 & 0 & 0 & 3 & 42 & 54 \\
\hline 3 & 3 June & $178^{\circ} 10^{\prime} 16^{\prime \prime}$ & $18^{\circ} 14^{\prime} 30^{\prime \prime}$ & 3 & 8 & 0 & 70 & 0 & 3 & 14 & 29 & 24 & 30 \\
\hline 4 & 3 June & $178^{\circ} 10^{\prime} 29^{\prime \prime}$ & $18^{\circ} 14^{\prime} 66^{\prime \prime}$ & 3 & 22 & 1 & 68 & 0 & 2 & 2 & 26 & 38 & 32 \\
\hline 5 & 3 June & $178^{\circ} 10^{\prime} 40^{\prime \prime}$ & $18^{\circ} 14^{\prime} 06^{\prime \prime}$ & 3 & 67 & 80 & 14 & 3 & 3 & 6 & 3 & 0 & 6 \\
\hline 6 & 3 June & $178^{\circ} 10^{\prime} 45^{\prime \prime}$ & $18^{\circ} 14^{\prime} 07^{\prime \prime}$ & 3 & \multicolumn{9}{|c|}{ Coarse coral rubble } \\
\hline 7 & 3 June & $178^{\circ} 10^{\prime} 35^{\prime \prime}$ & $18^{\circ} 14^{\prime} 15^{\prime \prime}$ & 3 & \multicolumn{9}{|c|}{ Coarse coral rubble } \\
\hline 8 & 3 June & $178^{\circ} 11^{\prime} 02^{\prime \prime}$ & $18^{\circ} 13^{\prime} 54^{\prime \prime}$ & 3 & 13 & 0 & 81 & 0 & 0 & 2 & 18 & 60 & 19 \\
\hline 9 & 3 June & $178^{\circ} 11^{\prime} 20^{\prime \prime}$ & $18^{\circ} 13^{\prime} 40^{\prime \prime}$ & 4 & 12 & 0 & 61 & 0 & 0 & 1 & 30 & 30 & 39 \\
\hline 10 & 3 June & $178^{\circ} 11^{\prime} 40^{\prime \prime}$ & $18^{\circ} 13^{\prime} 25^{\prime \prime}$ & 4 & 4 & 0 & 96 & 0 & 4 & 31 & 47 & 14 & 4 \\
\hline 11 & 6 June & $178^{\circ} 13^{\prime} 11^{\prime \prime}$ & $18^{\circ} 12^{\prime} 29^{\prime \prime}$ & 1 & 14 & 0 & 17 & 0 & 0 & 0 & 3 & 14 & 83 \\
\hline 12 & 6 June & $178^{\circ} 12^{\prime} 26^{\prime \prime}$ & $18^{\circ} 12^{\prime} 13^{\prime \prime}$ & 2 & 46 & 34 & 42 & 3 & 8 & 11 & 10 & 11 & 24 \\
\hline 13 & 6 June & $178^{\circ} 12^{\prime} 46^{\prime \prime}$ & $18^{\circ} 12^{\prime} 04^{\prime \prime}$ & 2 & 25 & 2 & 86 & 2 & 3 & 8 & 50 & 23 & 12 \\
\hline 14 & 7 June & $178^{\circ} 10^{\prime} 53^{\prime \prime}$ & $18^{\circ} 14^{\prime} 53^{\prime \prime}$ & 8 & 71 & 0 & 63 & 1 & 9 & 18 & 27 & 8 & 37 \\
\hline 15 & 7 June & $178^{\circ} 10^{\prime} 14^{\prime \prime}$ & $18^{\circ} 15^{\prime} 15^{\prime \prime}$ & 11 & 21 & 1 & 25 & 0 & 0 & 2 & 11 & 13 & 75 \\
\hline 16 & 7 June & $178^{\circ} 11^{\prime} 12^{\prime \prime}$ & $18^{\circ} 14^{\prime} 42^{\prime \prime}$ & 14 & 80 & 38 & 40 & 6 & 18 & 8 & 6 & 2 & 23 \\
\hline 17 & 7 June & $178^{\circ} 11^{\prime} 27^{\prime \prime}$ & $18^{\circ} 14^{\prime} 35^{\prime \prime}$ & 22 & 20 & 0 & 29 & 0 & 0 & 0 & 0 & 29 & 71 \\
\hline 18 & 7 June & $178^{\circ} 11^{\prime} 44^{\prime \prime}$ & $18^{\circ} 14^{\prime} 22^{\prime \prime}$ & 25 & 31 & 0 & 22 & 3 & 1 & 3 & 5 & 11 & 78 \\
\hline 19 & 7 June & $178^{\circ} 12^{\prime} 06^{\prime \prime}$ & $18^{\circ} 14^{\prime} 03^{\prime \prime}$ & 20 & 46 & 1 & 62 & 5 & 7 & 10 & 15 & 26 & 37 \\
\hline 20 & 7 June & $178^{\circ} 12^{\prime} 32^{\prime \prime}$ & $18^{\circ} 13^{\prime} 57^{\prime \prime}$ & 19 & 54 & 1 & 55 & 2 & 3 & 5 & 22 & 24 & 44 \\
\hline 21 & 7 June & $178^{\circ} 12^{\prime} 37^{\prime \prime}$ & $18^{\circ} 13^{\prime} 45^{\prime \prime}$ & 23 & 42 & 6 & 29 & 2 & 5 & 7 & 8 & 8 & 65 \\
\hline 22 & 7 June & $178^{\circ} 12^{\prime} 54^{\prime \prime}$ & $18^{\circ} 13^{\prime} 29^{\prime \prime}$ & 27 & 84 & 0 & 89 & 10 & 26 & 31 & 17 & 6 & 11 \\
\hline 23 & 7 June & $178^{\circ} 13^{\prime} 13^{\prime \prime}$ & $18^{\circ} 13^{\prime} 17^{\prime \prime \prime}$ & 31 & 60 & 1 & 48 & 4 & 8 & 11 & 13 & 12 & 51 \\
\hline 24 & 15 June & $178^{\circ} 15^{\prime} 52^{\prime \prime}$ & $18^{\circ} 10^{\prime} 07^{\prime \prime}$ & 13 & 17 & 0 & 25 & 0 & 0 & 0 & 2 & 23 & 75 \\
\hline 25 & 15 June & $178^{\circ} 16^{\prime} 14^{\prime \prime}$ & $18^{\circ} 11^{\prime} 17^{\prime \prime}$ & 2 & 100 & 24 & 74 & 20 & 25 & 22 & 8 & 1 & 2 \\
\hline 26 & 15 June & $178^{\circ} 15^{\prime} 35^{\prime \prime}$ & $18^{\circ} 10^{\prime} 57^{\prime \prime}$ & 13 & 89 & 34 & 63 & 20 & 20 & 15 & 7 & 2 & 3 \\
\hline 27 & 15 June & $178^{\circ} 16^{\prime} 02^{\prime \prime}$ & $18^{\circ} 11^{\prime} 30^{\prime \prime}$ & 17.5 & \multicolumn{9}{|c|}{ No sample retrieved } \\
\hline 28 & 15 June & $178^{\circ} 15^{\prime} 41^{\prime \prime}$ & $18^{\circ} 11^{\prime} 39^{\prime \prime}$ & 14.5 & \multirow{2}{*}{\multicolumn{9}{|c|}{ No sample retrieved }} \\
\hline 29 & 15 June & $178^{\circ} 15^{\prime} 18^{\prime \prime}$ & $18^{\circ} 11^{\prime} 54^{\prime \prime}$ & 16 & & & & & & & & & \\
\hline 30 & 15 June & $178^{\circ} 14^{\prime} 55^{\prime \prime}$ & $18^{\circ} 12^{\prime} 03^{\prime \prime}$ & 17.5 & \multicolumn{9}{|c|}{ No sample retrieved } \\
\hline 32 & 16 June & $178^{\circ} 11^{\prime} 55^{\prime \prime}$ & $18^{\circ} 12^{\prime} 54^{\prime \prime}$ & 1 & 9 & 1 & 81 & 1 & 1 & 10 & 40 & 30 & 18 \\
\hline 33 & 16 June & $178^{\circ} 12^{\prime} 17^{\prime \prime}$ & $18^{\circ} 13^{\prime} 11^{\prime \prime}$ & 3 & 14 & 0 & 91 & 0 & 1 & 6 & 66 & 19 & 9 \\
\hline 34 & 16 June & $178^{\circ} 12^{\prime} 36^{\prime \prime}$ & $18^{\circ} 13^{\prime} 04^{\prime \prime}$ & 2 & 84 & 15 & 68 & 0 & 0 & 1 & 23 & 44 & 18 \\
\hline
\end{tabular}

${ }^{a}$ ves, very coarse sand; cs, coarse sand; ms, medium sand; fs, fine sand; vfs, very fine sand.

carbonate (siliciclastic) component, mostly in the fine to very fine sand to mud fractions (Table 2). Most sediment samples (78\%) are found in this facies, which is distributed throughout much of the lagoon (Figure 8). Facies 2 sediments also show a wide range of mixing $\left(\mathrm{CaCO}_{3}\right.$ ranges from 2 to $84 \mathrm{wt} \%$ [Table 1]), but have a low average carbonate content of 28 wt\% (Table 2). Physical processes dominantly shape the grain size populations of facies 2, which is better sorted than facies 1 (Table 2), because the dominant allochthonous siliciclastic fraction has under- gone selective transport and sorting before deposition. Consequently, terrigenous sediments are near symmetrical, while mixed sediments are coarse skewed due to the in situ addition of coarser skeletal carbonates, mainly bivalve mollusks and Halimeda grains. Facies 2 is primarily controlled by siliciclastic sedimentation (supply) and benthic interreefal carbonate production.

Gross skeletal composition does not vary across the two identified facies, suggesting that the mollusk-Halimeda association is at least partly tolerant of water turbidity and 


\begin{tabular}{|c|c|c|c|c|c|}
\hline Folk Class (1968) & Mount Class (1985) & $\begin{array}{c}\text { Mean } \\
\text { grain size } \\
\quad(\phi)\end{array}$ & $\begin{array}{c}\text { Modal } \\
\text { grain size } \\
\quad(\phi)\end{array}$ & $\begin{array}{l}\text { Sorting } \\
\text { coefficient } \\
(\phi)\end{array}$ & Skewness \\
\hline Sandy mud & Allochemic mud & 3.86 & 5 & 0.8 & -0.36 \\
\hline Sandy mud & Terrigenous sandy mud & 4.01 & 5 & 0.56 & -0.11 \\
\hline Slightly gravely sandy mud & Terrigenous sandy mud & 3.13 & 5 & 1.15 & -0.03 \\
\hline Slightly gravely sandy mud & Allochemic mud & 3.46 & 4 & 0.9 & -0.05 \\
\hline Muddy sandy gravel & Muddy allochem carbonate gravel & -0.79 & -1 & 1.63 & 1 \\
\hline Muddy sand & Allochemic mud & 3.47 & 4 & 0.68 & -0.03 \\
\hline Muddy sand & Allochemic mud & 3.57 & 5 & 0.85 & -0.08 \\
\hline Slightly gravely sand & Terrigenous sand & 2.32 & 3 & 0.88 & 0.03 \\
\hline Sandy mud & Allochemic mud & 4.3 & 5 & 0.46 & -0.23 \\
\hline Muddy sandy gravel & Allochemic mud & 1.31 & -1 & 2.46 & 0.15 \\
\hline Slightly gravely muddy sand & Allochemic mud & 2.69 & 3 & 1.18 & 0.06 \\
\hline Muddy sand & Muddy allochem carbonate sand & 2.95 & 5 & 1.4 & 0 \\
\hline Slightly gravely sandy mud & Allochemic mud & 4.08 & 5 & 0.84 & -0.48 \\
\hline Muddy sandy gravel & Muddy allochem carbonate gravel & 0.84 & -1 & 2.35 & 0.51 \\
\hline Sandy mud & Allochemic mud & 4.21 & 5 & 0.46 & -0.25 \\
\hline Sandy mud & Allochemic mud & 4.03 & 5 & 1.11 & -0.52 \\
\hline Slightly gravely muddy sand & Allochemic mud & 3.04 & 5 & 1.58 & -0.4 \\
\hline Slightly gravely muddy sand & Muddy allochem carbonate sand & 3.44 & 5 & 1.25 & -0.35 \\
\hline Gravely mud & Allochemic mud & 3.13 & 5 & 1.78 & -0.72 \\
\hline Sand & Muddy allochem carbonate sand & 1.65 & 2 & 1.41 & 0.18 \\
\hline Slightly gravely muddy sand & Muddy allochem carbonate sand & 3.21 & 5 & 1.62 & -0.62 \\
\hline Sandy mud & Allochemic mud & 4.23 & 5 & 0.49 & -0.28 \\
\hline Gravely sand & Carbonate sand & 0.3 & 1 & 1.24 & 0.19 \\
\hline Sandy gravel & Muddy allochem carbonate gravel & 0.09 & -1 & 1.57 & 0.51 \\
\hline Slightly gravely sand & Terrigenous sand & 2.99 & 3 & 1.07 & 0.09 \\
\hline Sand & Allochemic mud & 2.8 & 3 & 0.73 & 0.32 \\
\hline Gravely muddy sand & Muddy allochem carbonate sand & 2.55 & 4 & 1.71 & -0.5 \\
\hline
\end{tabular}

siliciclastic sedimentation (see Discussion). Ubiquitous distribution of benthic interreefal carbonate producers and/or movement of the carbonate fraction within the narrow lagoon are also possible factors.

\section{DISCUSSION}

\section{Sediment Mixing}

Surface sediments of the Navua-Suva Lagoon, Fiji, are of two types: siliciclastics (volcaniclastics, and clays and other weathering products) and marine biogenic carbonates. The former are derived from the island terrain via weathering and fluvial (and coastal) transport, and the latter are supplied by production by benthic, mostly interreefal, organisms. The two resulting facies are both siliciclastic-carbonate mixtures, but differ in the degree of mixing.

Mount (1984) described four fundamental types of mixing: facies, source, punctuated, and in situ mixing. The first three types are offset in some way: either they are located at a boundary between more typical deposits 


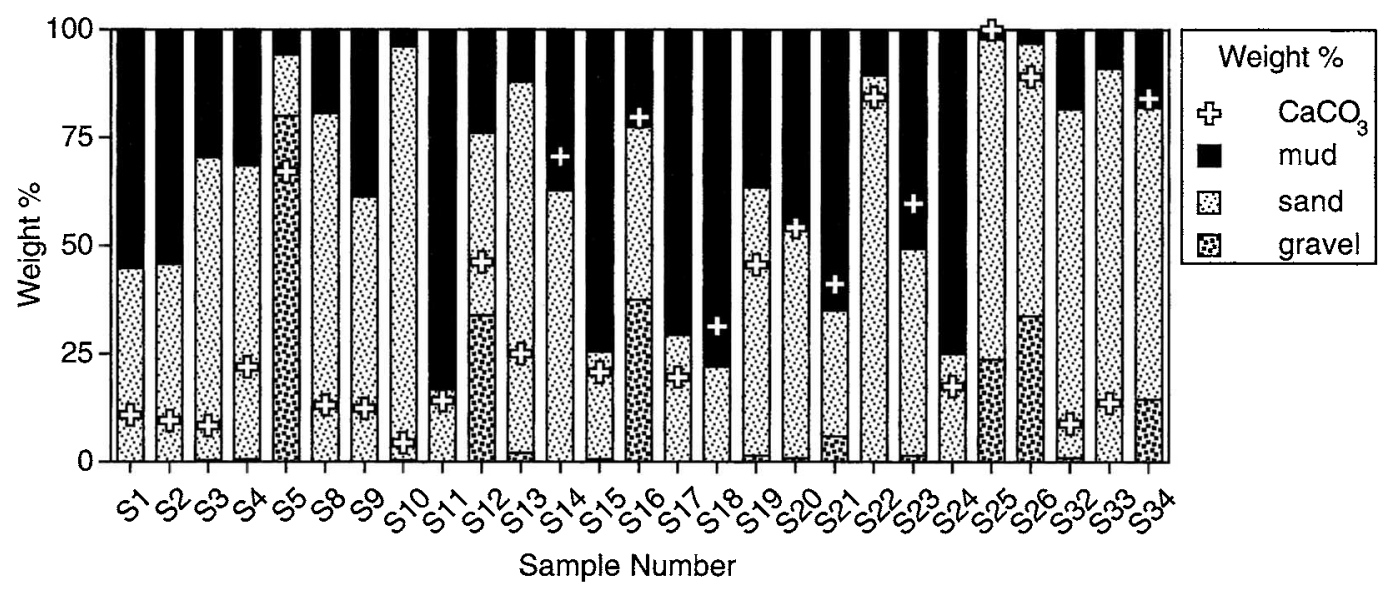

FIGURE 2. Bulk textural composition (weight\% gravel, sand, mud) and calcium carbonate content (weight\%) of NavuaSuva Lagoon sediments.

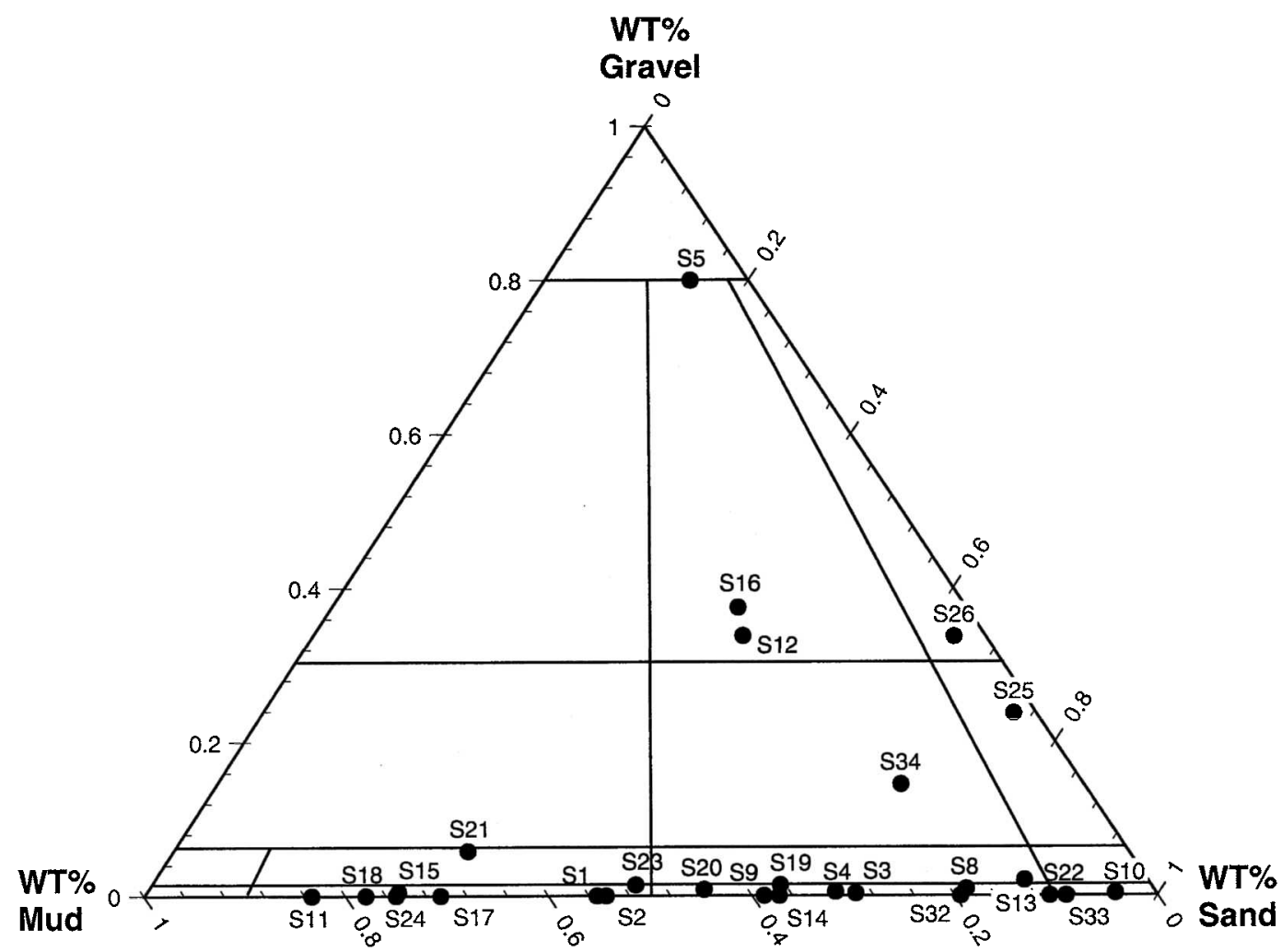

FIGURE 3. Distribution of sediments within ternary diagram used for classifying textural groupings using components gravel, sand, and mud (after Folk 1968). Sediment types fit into a continuous distribution from a few high-gravel lowmud samples, through to mostly sand to low-gravel high-mud samples. 


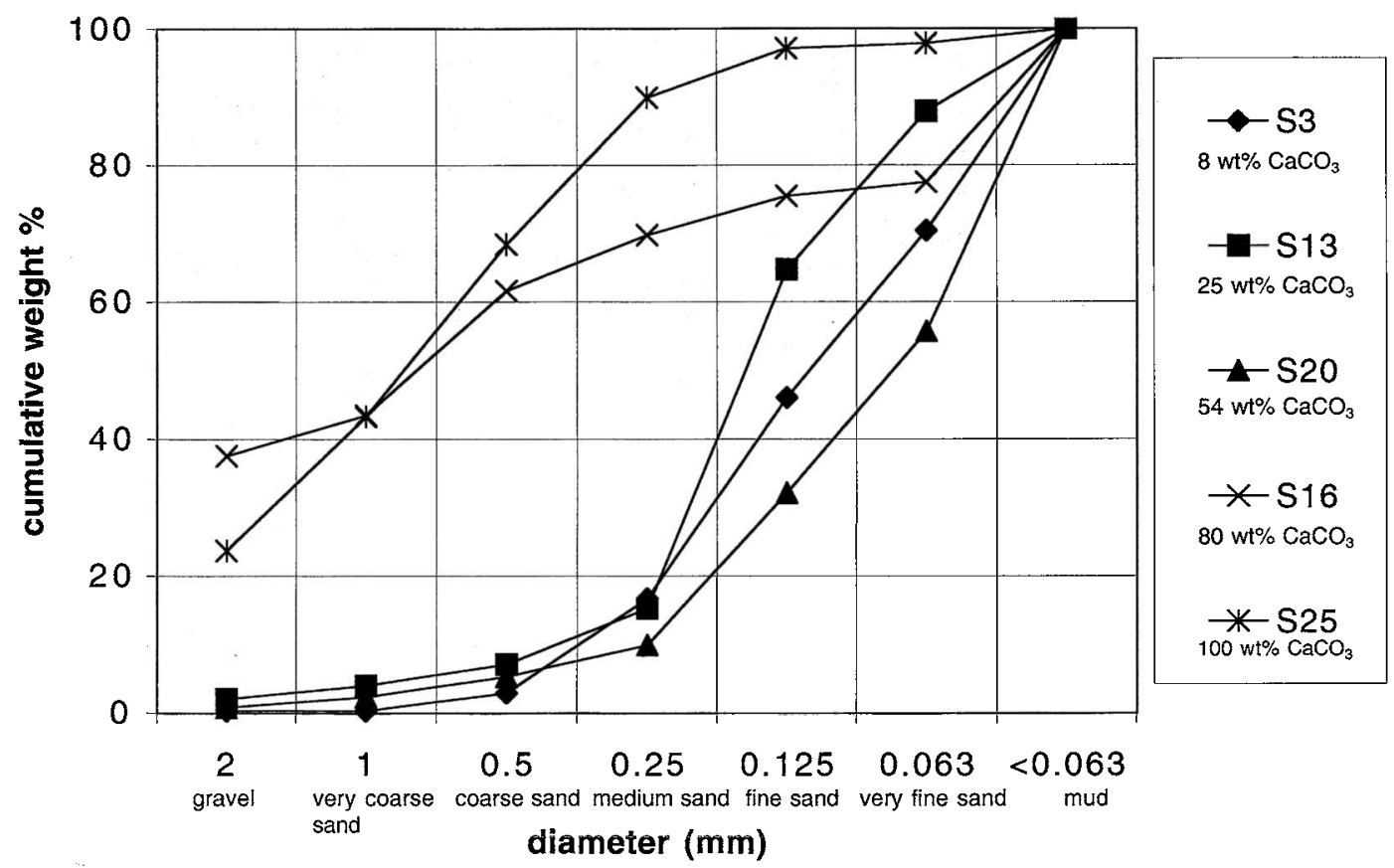

Figure 4. Cumulative weight frequency plot (based on seven grain size class intervals over one distribution) of selected samples with various degrees of mixing (wreight\% carbonate content).

(facies and punctuated) or they have been mixed postdepositionally (source). In situ mixing is the only type where carbonate deposition is occurring in the same location and at the same time as siliciclastic sedimentation.

In situ mixing best explains the sedimentary dynamics of the Navua-Suva Lagoon, where riverborne volcanic sediments are regularly washed into a tropical carbonate lagoon. Siliciclastic and carbonate sediment supplied to the lagoon is prevented from subsequent wave erosion by a protective, but dissected, barrier reef. Because the lagoon is so narrow, sediment dispersal extends over the entire width of the lagoon and cross-shelf processes are rapid. Carbonate production by benthic, interreefal organisms proceeds in the face of siliciclastic sedimentation (see later in this section), although some unknown degree of physiological stress might be assumed. Contemporaneous siliciclastic and carbonate sedimentation results in in situ mixing, which produces gradual, rather than sharply defined facies contrasts.
In situ mixing has been favored in temperate settings (Mount 1984) because temperate organisms may have higher tolerance levels to terrigenous sedimentation, or because carbonate sedimentation is taking place in siliciclastic, but sediment-starved, environments. Simone and Carannante (1988) suggested that tropical skeletal assemblages may deviate from the model "chloralgal" assemblage (Lees and Buller 1972) if changing environmental conditions (e.g., cold water intrusion, salinity changes, and nutrient increase) preclude its development. There is some indication that the mollusk-Halimeda assemblage of the Navua-Suva Lagoon is at least partly tolerant of water turbidity and sedimentation and is thus a factor in facies development. Many mollusks are filter feeders or infaunal detritus feeders and may benefit from additional food sources in the water column; infaunal types are mobile and able to track the sediment-water interface. Introduction of nutrients from land or oceanic sources is predicted to favor algal growth (Hallock 


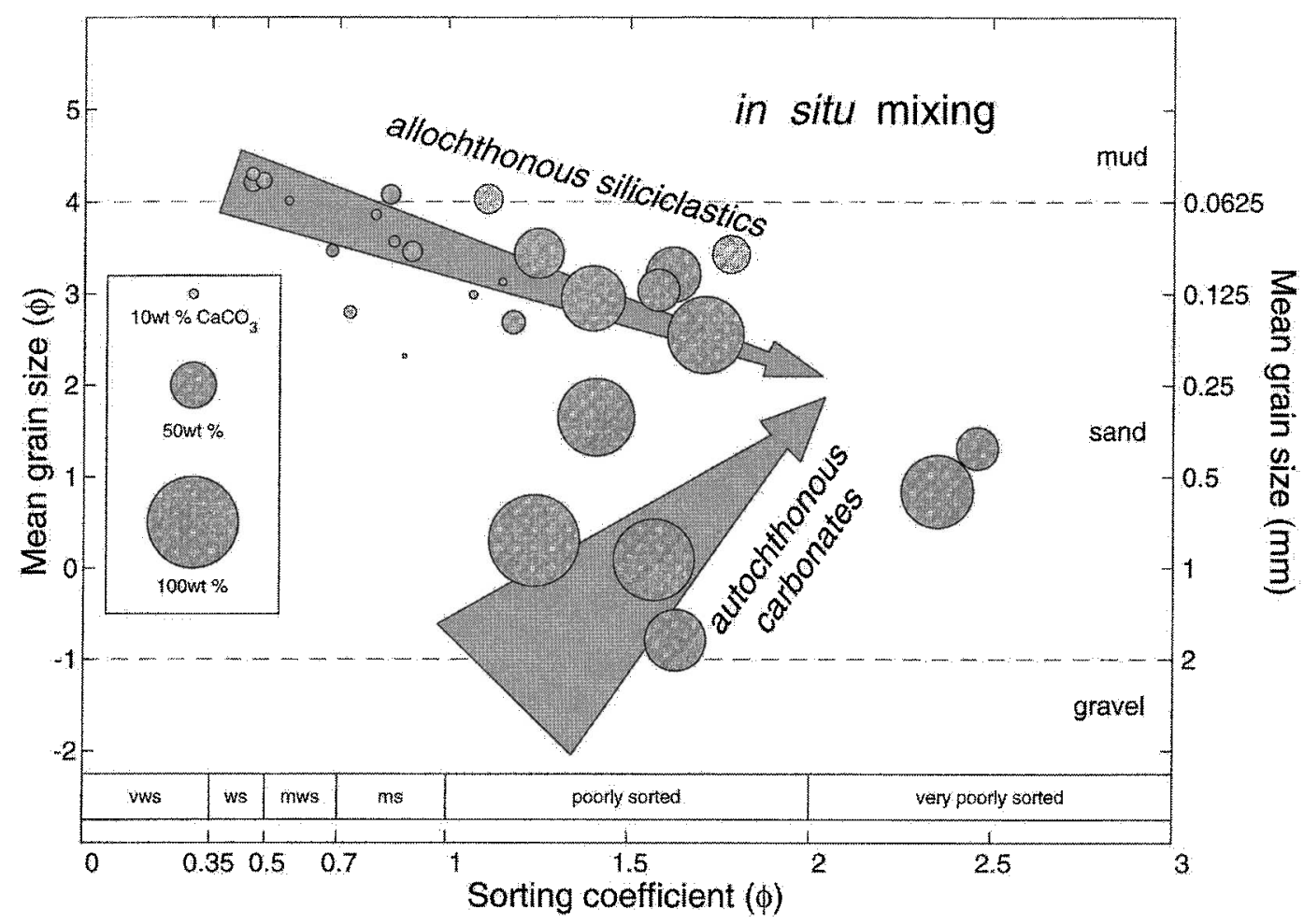

Frgure 5. Relationship between mean grain size ( $\Phi, \mathrm{mm}, y$ axis), sorting coefficient ( $\Phi, x$ axis), and calcium carbonate content (weight\%, bubbles) (vws, very well sorted; ws, well sorted; mws, moderately well sorted; ms, moderately sorted).

and Schlager 1986, Drew 2001). Acker and Stearn (1988) stated that Halimeda is more tolerant of water turbidity and sedimentation than other coral reef organisms. Living $\mathrm{Hal}$ imeda are known from water depths greater than $100 \mathrm{~m}$ where light is severely reduced (Hillis-Colinvaux 1986). A number of workers (Weiss et al. 1978, Murray et al. 1983, D'Aluisio-Guerrieri and Davis 1988, Masse et al. 1989, Fornos et al. 1990, Freile and Hillis 1997, Roberts and Sydow 1997) have described the importance of Halimeda in mixed carbonate-siliciclastic settings or in environments under terrigenous influence. Weiss et al. (1978), Fornos et al. (1990), and Tomascik and Mah (1994) reported living Halimeda in seemingly suboptimal conditions (with respect to corals) of much reduced circulation and/or elevated salinities. Halimeda is also less susceptible to environmental stresses such as phytoplanktonic blooms (Adjeroud et al. 2001), further attesting to the alga's environmental tolerance.

Less is known about the effects of siliciclastics on the different reef types (barrier, lagoon patch, and fringing) of the NavuaSuva Lagoon, because they have not been addressed in this study. It is likely that they have different susceptibilities to environmental stresses such as sedimentation (Holthus 1991) due to their morphology and positioning with respect to sea level, river mouth, shoreline, and open ocean. Facies mixing will be locally important around such reefs.

Although we have discounted source and punctuated mixing on the argument that sediment fluxes are modern and contemporaneous, relict or palimpsest sediments have been documented in other high volcanic islands (Richmond 1990). The possibility of such 


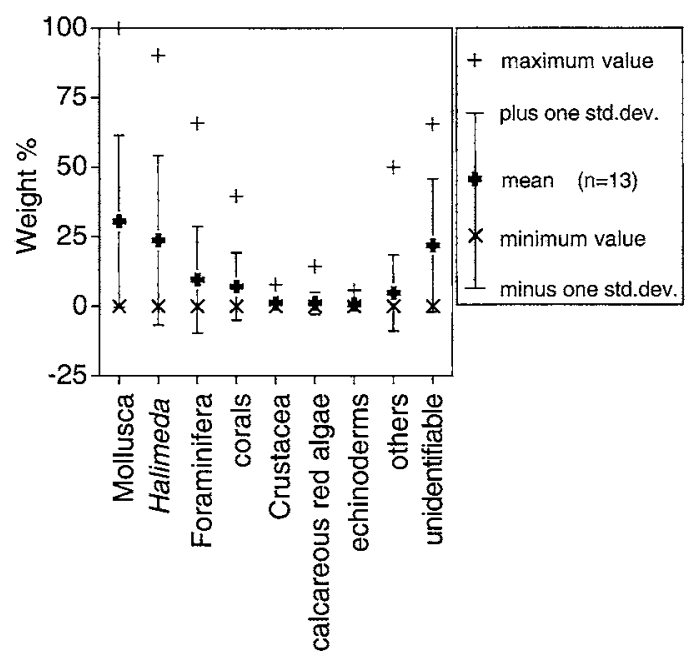

FIGURE 6. Results of constituent component analysis of gravel fractions $(>2 \mathrm{~mm}$ ) of Navua-Suva Lagoon surface samples ( $n=13$; std. dev. = standard deviation). "Others" includes minor components (agglutinations, barnacle shells, bryozoans, chiton shells, fish scales, soft coral spicules, worm tubes). "Unidentifiable" includes calcareous material not identified in this study.

sediments contributing to Navua-Suva Lagoon sediments needs further study, but any contribution is likely to be quickly diluted by modern sediments in this geologically compressed system.

\section{Navua-Suva Lagoon Sediment Budget}

No reliable data are currently available on riverine sediment fluxes and carbonate production on Viti Levr. A first approximation of the total amount of sediment delivered by the Navua River can be made by using the method described in Asquith et al. (1994), who applied the Fournier equation for catchments with high relief and humid climates to estimate suspended sediment yield:

$$
S_{y}=52.49 p^{2} / P-513.21 \text { (Fournier 1960) }
$$

where $S_{y}$ is sediment yield $\left(\mathrm{m}^{3} / \mathrm{km}^{2} / \mathrm{yr}\right), p$ is maximum mean monthly rainfall $(\mathrm{mm})$, and $P$ is mean annual rainfall $(\mathrm{mm})$ over the catchment area. Using an average $p^{2} / P$ value of 60 for the Navua River catchment, a specific gravity of 2.1 to 2.6 (Liedtke 1988, in Asquith et al. 1994), and a total drainage area of 1220 $\mathrm{km}^{2}$, the Navua River would yield between $\sim 7$ and 8 million tonnes of sediment per year $(\mathrm{Mt} / \mathrm{yr})$, or about $9 \%$ of the total estimated for Viti Levu (see Asquith et al. 1994). In comparison, the Rewa River, which is the largest river and drains about one-third (2917 $\mathrm{km}^{2}$ ) of Viti Levu, yields an estimated $26 \%$ (19-24 Mt/yr) (Asquith et al. 1994) of the island's total.

Carbonate production has not been measured in the Navua-Suva Lagoon, but can be inferred from other sources. If we assume a calcium carbonate production of $2 \mathrm{~kg} \mathrm{CaCO} /$ $\mathrm{m}^{2} / \mathrm{yr}$ for a "typical" shallow lagoon with patch reefs (after Kinsey and Hopley 1991), and an approximate figure of $45 \mathrm{~km}^{2}$ for the area of interest, we derive lagoon production of $\sim 0.09 \mathrm{Mt} / \mathrm{yr}$.

We can now attempt to estimate the proportion of siliciclastic sediment that reaches the lagoon and that which bypasses it, assuming that all siliciclastic material is delivered by the Navua River and all siliciclastics delivered and all carbonate produced are accumulating. If carbonate production is scaled to $0.1 \mathrm{Mt} / \mathrm{yr}$, given the known high productivity of Halimeda (Hillis 1997), and average siliciclastic content in lagoon sediments is about 1.6 times greater than the average carbonate fraction, then only $3 \%(\sim 0.2 \mathrm{Mt} / \mathrm{yr})$ of the total sediment flux ( $7 \mathrm{Mt} / \mathrm{yr})$ reaches the Navua-Suva Lagoon floor and at least $97 \%$ ( $6.8 \mathrm{Mt} / \mathrm{yr}$ ) must bypass the study area.

Although the figures in this budget are only approximate, they demonstrate the general principle that must operate in such systems and that we propose as our model. Rather high relief provides an abundant supply of terrigenous sediment delivered to the coast by rivers. Most of the high sediment load must bypass the shelf; only a fraction of the supply is retained in coastal lagoons. The Navua-Suva Lagoon would otherwise have been filled up in less than two centuries ( $\sim 179$ yr). Bypassing is mostly effected directly due to the small size of the lagoon and the presence of reef channels. Other minor mechanisms fencing off siliciclastics include temporary storage in sediment bodies such as 


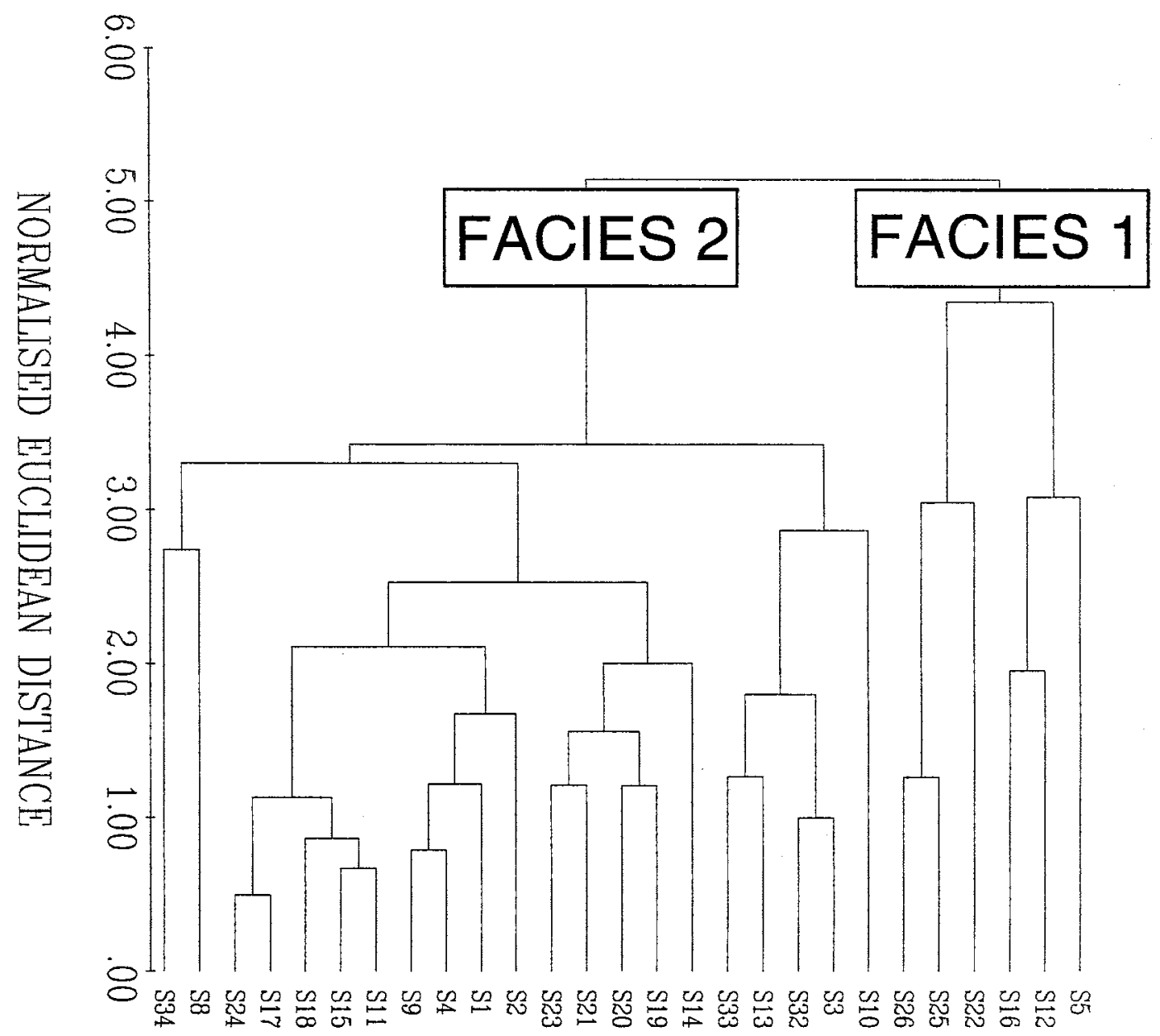

Figure 7. Results of cluster analysis of sediment samples based on grain-size data (seven grain size classes) and carbonate content. Two sediment facies are identified (see Table 2, text).

river deltas and beaches. Shoaling of the lagoon in the southwest (Figure 1) and the results of this study, however, suggest that terrigenous material is accumulating. The open marine environment adjacent to this coast is typically a carbonate-dominated system where detrital carbonate sediments from the reef complexes combine with autochthonous biogenic carbonate sediment in the lagoon. The environmental tolerances of benthic, interreefal organisms (Mollusca, Hali$m e d a)$ allow carbonate production to proceed at the current rate of siliciclastic input, resulting in mixed sediments.
The Navua River and other smaller streams flow year-round and carry substantial suspended sediment as inferred from discoloration. Peak flows capable of moving considerable bed loads are brief, episodic events related to periods of heavy rainfall, particularly in upstream areas. Carbonate production proceeds year-round under conditions favoring a somewhat sediment-tolerant suite of benthic interreefal organisms, which endure elevated turbidities (mollusks, Halimeda), are capable of escaping burial (mollusks), and/or are characterized by short life spans and high turnover rates (Halimeda). Although storms 
TABLE 2

Textural Characteristics of Navua-Suva Lagoon Sediment Facies

\begin{tabular}{|c|c|c|}
\hline Sedimentary Parameters & $\begin{array}{c}\text { Facies } 1(n=6) \\
\text { average } \pm \mathrm{SD}\end{array}$ & Facies $2(n=21)$ average $\pm S D$ \\
\hline Mean depth (m) & 10 & 10 \\
\hline $\mathrm{CaCO}_{3}(\mathrm{wt} \%)$ & $78 \pm 19$ & $28 \pm 23$ \\
\hline Gravel (wt\%) & $35 \pm 26$ & $1 \pm 3$ \\
\hline Total sand (wt\%) & $54 \pm 27$ & $56 \pm 24$ \\
\hline Vety coarse sand & $10 \pm 8$ & $1 \pm 2$ \\
\hline Coarse sand & $17 \pm 9$ & $2 \pm 3$ \\
\hline Medium sand & $15 \pm 9$ & $6 \pm 8$ \\
\hline Fine sand & $8 \pm 4$ & $22 \pm 17$ \\
\hline Very fine sand & $4 \pm 4$ & $25 \pm 13$ \\
\hline Mud (wt\%) & $11 \pm 10$ & $43 \pm 25$ \\
\hline \multirow[t]{3}{*}{ Folk (1968) class } & \multirow[t]{3}{*}{ Muddy sandy gravel $(50 \%)^{a}$} & Sandy mud $(29 \%)^{a}$ \\
\hline & & Slightly gravely muddy sand (19\%) \\
\hline & & Slightly gravely sandy mud (14\%) \\
\hline Mount (1985) class & $\begin{array}{l}\text { Muddy allochemic } \\
\text { carbonate gravel (50\%) }\end{array}$ & Allochemic mud $(62 \%)$ \\
\hline \multirow[t]{2}{*}{ Mean grain size } & Coarse sand $(50 \%)$ & Very fine sand ( $43 \%)$ \\
\hline & Medium sand $(33 \%)$ & Mud $(29 \%)$ \\
\hline Modal grain size & Fine gravel $(67 \%)$ & Mud $(67 \%)$ \\
\hline \multirow[t]{2}{*}{ Sorting coefficient } & Poorly sorted $(67 \%)$ & Poorly sorted (43\%) \\
\hline & Very poorly sorted (33\%) & Moderately sorted ( $38 \%$ ) \\
\hline \multirow[t]{2}{*}{ Skewness } & Strongly fine skewed $(50 \%)$ & Strongly coarse skewed (38\%) \\
\hline & Fine skewed $(50 \%)$ & Near symmetrical (38\%) \\
\hline
\end{tabular}

${ }^{a}$ Ordered modes explaining $\geq 50 \%$ of samples.

and cyclones usually create conditions of high rainfall that control the siliciclastic supply rate, they are also responsible for much of the removal of lagoonal sediment (Hubbard 1990, Li et al. 1998). The Navua-Suva Lagoon is a dynamic setting with episodic high siliciclastic supply, continuous carbonate production, and intermittent partial removal of both.

It is conceivable that recent environmental changes have facilitated sediment mixing in the Navua-Suva Lagoon. Recent sea-level stabilization and a mid- to late Holocene relative sea-level fall $(<\sim 3000-4000$ yr before present) acted to bring carbonate and terrigenous sediment sources closer together; river mouths prograded seaward and migrated to their current position behind the reefs (Nunn 1990), lagoon volume decreased, and warmer, wetter conditions increased sediment supply. Detailed examination of the stratigraphy of the sediments in the NavuaSuva Lagoon would permit a better recon- struction of the process-response systems that operate in such a complex coastal system (Heap et al. 2001).

\section{Other High Volcanic Islands}

Terrigenous sediments are considered to be common in settings near high islands (Stark and Dapples 1941, Masse et al. 1989). Mixing of siliciclastics and carbonates has been described in high island settings from both the Indo-Pacific (Chevalier 1973a,b, Guilcher 1985, Masse et al. 1989, Richmond 1990) and the Caribbean (Schneidermann et al. 1976, D'Aluisio-Guerrieri and Davis 1988, Pilkey et al. 1988, Dey and Smith 1989, Acker and Stearn 1990, Heikoop and Risk 1993), including beaches, reef-protected lagoons, and open, high-energy shelves. Davis (1920) and Menard (1983) theorized on the relations between an eroding volcanic island and coral reef growth. Menard (1983) suggested that the capture of sand and mud from stream 


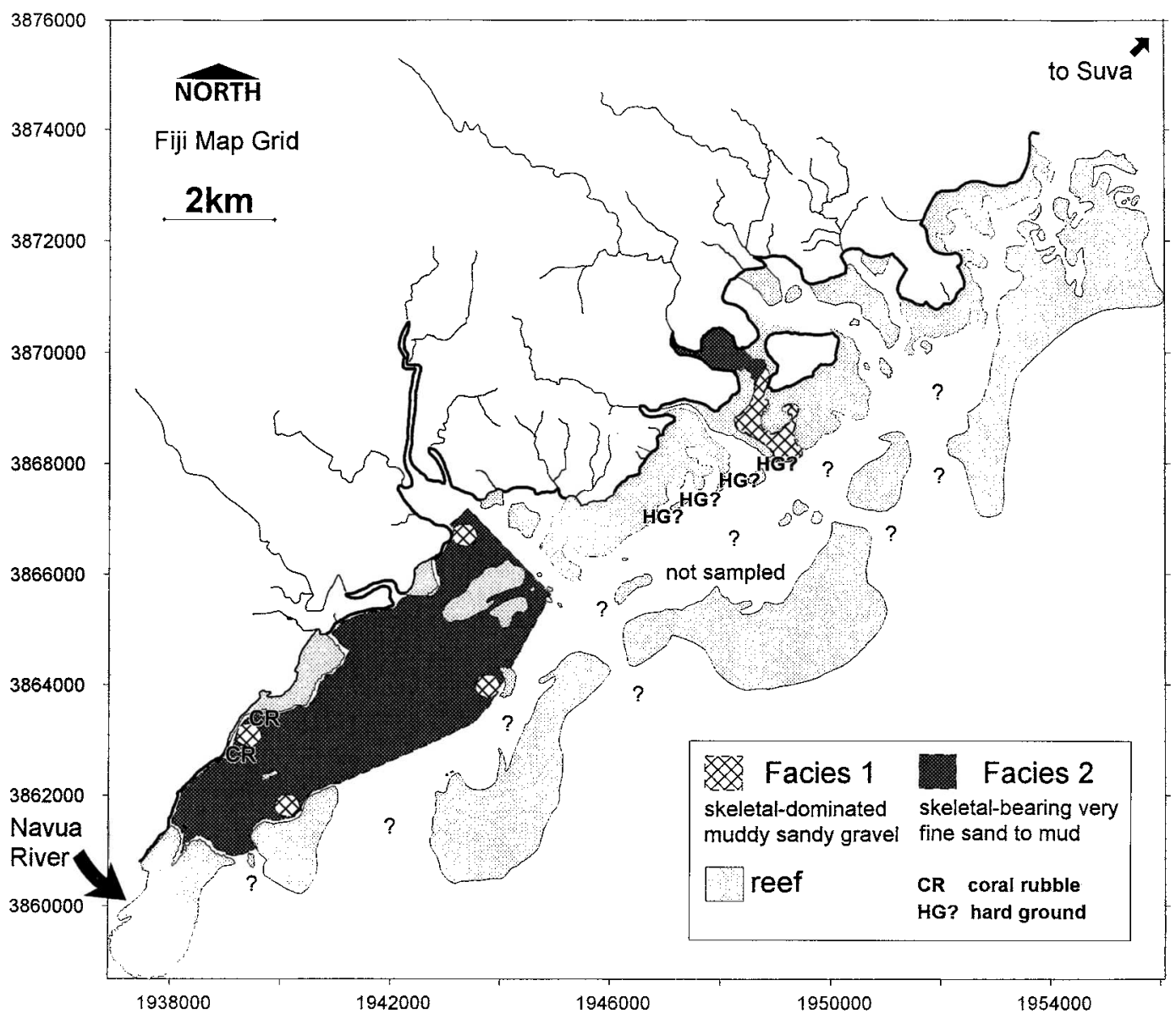

FIGURE 8. Areal distribution of surface sediment facies (as identified in Figure 7) in the Navua-Suva Lagoon. Note that coordinate system is Fiji Map Grid.

erosion by barrier reefs encircling volcanoes is a factor in compensating for isostatic uplift. Only the lagoons studied by Guilcher (1985) (Bora Bora, Guadeloupe, Mayotte, and Tahiti) are similar in external geomorphology and environmental setting to the Navua Suva Lagoon (Table 3) and where in situ mixing would be predicted. Guilcher (1985) concluded that for tropical volcanic islands with high rainfall, the percentage of biogenic carbonates versus terrigenous sediment is a function of the ratio of area covered by the central volcanic island to that covered by the lagoon. Bora Bora (low ratio) and Tahiti (high ratio) provided the end-members along Guilcher's
(1985) continuum, the former being characterized by carbonate dominance, the latter by a high degree of mixing. New Caledonia has both a relatively large terrestrial and lagoonal area with consequently variable sediment mixing. Viti Levu, on the other hand, has a very high island to lagoon area ratio.

Lagoonal carbonate sedimentation is known to be distinct from that on reefs (Milliman 1974, Chevillon 1996). The main sediment formers, mollusks, Halimeda, and Foraminifera, seem to be consistent over a range of high island lagoons with various degrees of mixing (Vieques [D'AluisioGuerrieri and Davis 1988] and Mayotte 
TABLE 3

Environmental Setting, Geomorphology, and Sedimentary Character of Navia-Suva Lagoon, Southeast Viti Levu, Fiji

\begin{tabular}{|c|c|}
\hline Parameter & Navua-Suva Lagoon Attributes \\
\hline \multicolumn{2}{|l|}{ Setting } \\
\hline Latitude & $18^{\circ} \mathrm{S}$ \\
\hline Depositional setting & Island arc, rimmed island shelf (lagoon and reef) \\
\hline Tectonic setting & Relatively stable during Late Quaternary \\
\hline Maximum land elevation & $1,323 \mathrm{~m}$ \\
\hline Land topography & Steep $\left(68 \%>18^{\circ}\right.$ slope angles $)$ \\
\hline Rainfall & High $(3-5 \mathrm{~m} / \mathrm{yr})$, seasonal, short-term variability \\
\hline \multicolumn{2}{|l|}{ Lagoon dimensions } \\
\hline Water depth & $16 \mathrm{~m}$ (average) \\
\hline Minimum/maximum lagoon width & $200 / 4,000 \mathrm{~m}$ \\
\hline \multicolumn{2}{|l|}{ Lagoon water properties } \\
\hline Temperature & Warm $\left(24-26^{\circ} \mathrm{C}\right)$ \\
\hline Salinity & Normal (34-35 psu) \\
\hline Circulation & Lagoonal, connected to ocean, tidal, wave, storm, and cyclone influence \\
\hline \multicolumn{2}{|l|}{ Terrigenous deposition } \\
\hline Source & Tertiary uplifted, collisional island-arc volcanics and sedimentary rocks \\
\hline Mode of entry & Navua River, numerous streams and creeks \\
\hline Supply & High $(0.2 \mathrm{Mt} / \mathrm{yr})$, allochthonous \\
\hline Potential sedimentation & $4 \mathrm{~kg} / \mathrm{m}^{2} / \mathrm{yr}$ \\
\hline Potential accumulation ${ }^{a}$ & $264 \mathrm{~cm} / \mathrm{kyr}$ \\
\hline Human influence & Likely \\
\hline \multicolumn{2}{|l|}{ Carbonate deposition } \\
\hline Source & Lagoon interreefal benthos \\
\hline & Locally fringing, patch, and barrier reefs \\
\hline Mode of entry & Over entire area \\
\hline Supply & $0.1 \mathrm{Mt} / \mathrm{yr}$, in situ \\
\hline Potential sedimentation & $2.2 \mathrm{~kg} / \mathrm{m}^{2} / \mathrm{yr}$ \\
\hline Potential accumulation ${ }^{b}$ & $210 \mathrm{~cm} / \mathrm{kyr}$ \\
\hline Human influence & Low at time of study \\
\hline Typical facies & Mollusca, Halimeda \\
\hline Carbonate-siliciclastic mixing & In situ \\
\hline Aerial extent & Small (at least $\sim 45 \mathrm{~km}^{2}$ ) \\
\hline
\end{tabular}

Assuming a density of $1,000 \mathrm{~kg} / \mathrm{m}^{3}$ and $60 \%$ porosity.

${ }^{b}$ Assuming a density of $600 \mathrm{~kg} / \mathrm{m}^{3}$ and $60 \%$ porosity.

[Masse et al. 1989]), as well as atoll lagoons with no mixing (unpublished compiled data). This indicates that benthic interreefal carbonate producers are not specialized to cope with siliciclastic sedimentation, but rather endure it with an unknown degree of physiological stress. By considering further examples of high volcanic islands of different dimensions, thus extending Guilcher's (1985) continuum, it may be possible to determine the upper limit of terrigenous influence on lagoon carbonate production. Clearly, there is a need to further investigate the envi- ronmental tolerances of important carbonate producers (other than coral) to water turbidity and sedimentation.

A total of 62 Pacific high volcanic islands (generally less than $10,000 \mathrm{~km}^{2}$ in area) with active drainage systems yield an estimated $1.2 \times 10^{9}$ tonnes of sediment per year, or about $6 \%$ of the world total, despite having less than $0.2 \%\left(136,935 \mathrm{~km}^{2}\right)$ of the world's drainage area (calculated from Asquith et al. 1994). Most of the sediment escapes to the deep ocean, making high volcanic islands important exporters not only of carbonates and 
nutrients (see Acker et al. 1997), but also of siliciclastic sediment. Coral reefs are one of the most productive carbonate environments in the ocean (Milliman 1993); in the Pacific islands they cover an area of approximately $35,000 \mathrm{~km}^{2}$ (excluding Papua New Guinea), or about $14 \%$ of the world total (from Bryant et al. 1998). Although the lagoon in this study is small (Table 3), it is common for highrelief highlands such as Viti Levu and others in the Pacific to have similar environments along their coasts. Mixing of siliciclastics and carbonate sediments will be important in such lagoons, and will be more common than previously appreciated.

Without knowledge of the stratigraphic context of the Navua-Suva Lagoon it is difficult to predict the preservation potential of mixed lagoonal sediments. In protected lagoons of tectonically active areas it is expected to be high (D'Aluisio-Guerrieri and Davis 1988), producing a stratigraphic record with a relatively extensive marine carbonate component and local accumulations of mixed carbonate-siliciclastic sediments. The presence of such mixed facies would be of particular importance in reconstructing the paleogeography and depositional environments in which mixed facies accumulated.

\section{Implications of Lagoonal Mixed Sediments}

Siliciclastic sediment in the Navua-Suva Lagoon links coastal marine ecosystems to the terrestrial realm via rainfall and runoff. Runoff is a compound variable, which can include freshwater, sediments, chemicals, nutrients, and other pollutants. Siliciclastics are also physically different in, for example, size, hardness, and mineralogy from carbonates. Terrigenous mixing, therefore, has the potential to affect a wide range of ecological and physical aspects of high volcanic island lagoons, both within the water column, and at and below the sediment-water interface. Peoples in the South Pacific rely heavily on the "health" of their coastal resources, so when runoff is impairing the performance of ecosystems such as lagoons and coral reefs, it becomes a management issue. A combined terrestrial-marine "landscape" or "ecoscape" approach to management (and science) is increasingly being advocated from a number of different perspectives (e.g., Soicher and Peterson 1997, Aubanel et al. 1999, Heyman and Kjerfve 1999, Mueller-Dombois 1999, Nittrouer and Driscoll 1999).

The balance between siliciclastic and carbonate sediments in the Navua-Suva Lagoon, although not very well constrained by our budget calculations, may be a fine one. Processes that increase the supply and deposition of siliciclastics, be they natural (e.g., climate change) or human-induced (e.g., land use changes, shoreline modifications, climate change), may have detrimental consequences on coastal ecosystems. However, because landward sediment storage in rivers and streams of high volcanic islands is negligible, it should be possible to assess relatively quickly short-term (human) changes made to sediment loads through monitoring. Natural phenomena (e.g., El Niño) will require longer-term assessment, as well as other factors introducing variability (e.g., frequency of hurricanes and flood events). Relating changing coastal sedimentation to some human cause, however, has to be done within the natural geomorphological context of coastal zones (Hands et al. 1993). A feature of mixed lagoons will be the presence of natural siliciclastic sediment bodies, which, under changing environmental conditions and natural geomorphic change (e.g., sea level rise), may contribute to water turbidity unrelated to human activity.

In view of ever-increasing development pressures on land and at the coast, there is an urgent need to develop our understanding of physical processes in high volcanic islands and to include both terrestrial and marine realms in planning and management exercises. A better understanding of sediment sources and sinks is expected to lead to improved resource conservation and shoreline management of coastal zones (Hooke et al. 1996, Harney et al. 1999, Nittrouer and Driscoll 1999).

\section{CONCLUSIONS}

1. Navua-Suva Lagoon sediments are mixed carbonate-siliciclastics characterized by a high 
insoluble load, small grain size, a wide range of textures, and a high degree of mixing. A large active river draining an eroding hinterland suggests that the main source of siliciclastic material is modern and derived from the central volcanic island mass. Carbonate production is mostly accomplished by the lagoon benthos, characterized by a molluskHalimeda skeletal association.

2. Two sediment facies are delineated: skeletal-dominated : muddy sandy gravel (facies 1) and skeletal-bearing very fine sand to mud (facies 2). The texture, composition, and distribution of sedimentary facies are controlled by the adjacent shallow-marine area and its carbonate sediment productivity, and by sediment dispersal processes from siliciclastic point sources across a narrow lagoon.

3. Preliminary budget calculations show that siliciclastics are supplied at about twice $(0.2 \mathrm{Mt} / \mathrm{yr})$ the rate of potential carbonate production $(0.1 \mathrm{Mt} / \mathrm{yr})$, which is not enough to inhibit carbonate production. There is some indication that the mollusk-Halimeda assemblage of the Navua-Suva Lagoon is at least partly tolerant of water turbidity and is thus a factor in facies development. Most $(97 \%, \sim 6.8 \mathrm{Mt} / \mathrm{yr})$ of the total terrigenous flux is bypassed into the deep ocean. The lagoon budget, and thus mixed lithologies, are maintained by current siliciclastic influx and export rates, and the carbonate production potential of the lagoon.

4. The combination of allochthonous terrigenous siliciclastic and autochthonous marine skeletal carbonate sedimentation results in true syndepositional (in situ) mixing. Mixed siliciclastic and carbonate sediments are common in a variety of tropical high volcanic island lagoons, and the ratio is expected to vary according to the configuration of island size and lagoon area (Guilcher 1985). Island geomorphology (high relief, small area) is conducive to producing mixed siliciclasticcarbonate lagoons along adjacent, mostly carbonate coasts of oceanic islands. Tropical in situ carbonate-siliciclastic mixing is probably both important and more common than previously appreciated.

5. High volcanic islands are well suited to the study of carbonate-siliciclastic interac- tions due to their young geologic age and the juxtaposition of siliciclastic and carbonate sediment sources. Important ecological, sedimentological, and geological questions could be addressed in high volcanic island settings. Such knowledge of physical processes will be indispensable for purposes of resource conservation and management issues, particularly in an era of expected global climate change.

\section{ACKNOWLEDGMENTS}

The results of this study form part of a M.Sc. thesis completed by O.A.G. under the auspices of a bilateral student exchange agreement between the University of Otago (UO) and the University of the South Pacific (USP), and the support of the Mineral Resources Department (MRD) of Fiji. O.A.G. thanks Professor Philip Mladenov (UO), Professor Robin South and Johnson Seeto of the Marine Studies Programme (MSP) at USP, thesis supervisors Abigail Smith and Ross Vennell (both UO), and Gary Yeo, Graeme Wheller, Tevita Vuibau, and Ratu Isei Rayawa (all MRD), the Tui Namosi, and the Government of Fiji. Robert Smith, Michel Larue, and Sunita Prasad of the South Pacific Applied Geoscience Commission (SOPAC) provided additional assistance. Chris Old is thanked for drafting Figure 5. Critical comments made by Professor Cam Nelson (University of Waikato) and two anonymous reviewers helped focus ideas and improve the overall quality of the paper.

\section{Literature Cited}

Acker, J. G., C. W. Brown, and A. C Hine. 1997. The 'CORSAGE' program: Continuous orbital remote sensing of archipelagic geochemical effects. Int. J. Remote Sens. 18:305-321.

Acker, K. L., and C. W. Stearn. 1988. Biological and sedimentological changes across the carbonate-siliciclastic transition, northeast Barbados, W. I. Proc. 6th Int. Coral Reef Symp., Townsville, Australia 3:319-324.

-1 1990. Carbonate-siliciclastic facies transition and reef growth on the north- 
east coast of Barbados, West Indies. J. Sediment. Petrol. 60:18-25.

Adjeroud, M., S. Andréfoüet, and C. Payri. 2001. Mass mortality of macrobenthic communities in the lagoon of Hikueru Atoll (French Polynesia). Coral Reefs 19:287-291.

Asquith, M., F. Kooge, and R. J. Morrison. 1994. Transporting sediments via rivers to the ocean, and the role of sediments as pollutants in the South Pacific. South $\mathrm{Pa}$ cific Regional Environment Program Reports and Studies Series, No. 72, Apia, Western Samoa.

Aubanel, A., N. Marquet, J. M. Colombani, and B. Salvat. 1999. Modifications of the shoreline in the Society Islands (French Polynesia). Ocean Coast. Manage. 42:419438.

Baines, G. B. K., and R. J. Morrison. 1990. Marine pollution from landuse in the Pacific Island region. Mar. Pollut. Bull. 21:506-515.

Best, M. M. R., and S. M. Kidwell. 2000a. Bivalve taphonomy in tropical mixed siliciclastic-carbonate settings. I. Environmental variation in shell condition. Paleobiology 26:80-102.

-2000b. Bivalve taphonomy in tropical mixed siliciclastic-carbonate settings. II. Effect of bivalve life habits and shell types. Paleobiology 26:103-115.

Bryant, D., L. Burke, J. McManus, and M. Spalding. 1998. Reefs at risk: A map-based indicator of threats to the world's coral reefs. World Resources Institute, International Center for Living Aquatic Resources Management, World Conservation Monitoring Centre, United Nations Environment Programme, Washington, D.C.

Chevalier, J. P. 1973a. Geomorphology and geology of coral reefs in French Polynesia. Pages 113-142 in O. A. Jones and R. Endean, eds. Biology and geology of coral reefs. Vol. 1. Geology 1. Academic Press, New York.

. 1973b. Coral reefs of New Caledonia. Pages 143-168 in O. A. Jones and R. Endean, eds. Biology and geology of coral reefs. Vol. 1. Geology 1. Academic Press, New York.
Chevillon, C. 1996. Skeletal composition of modern lagoon sediments in New Caledonia: Coral, a minor constituent. Coral Reefs 15:199-207.

Clarke, K. R., and R. M. Warwick. 1994. Change in marine communities: An approach to statistical analysis and interpretation. National Environment Research Council, United Kingdom.

Crozier, M. J., R. Howorth, and I. J. Grant. 1981. Landslide activity during cyclone Wally, Fiji: A case study of Wainitubatolu catchment. Pacific Viewpoint 22:69-88.

D'Aluisio-Guerrieri, G. M., and R. A. Davis Jr. 1988. Infilling of coastal lagoons by terrigenous siliciclastic and marine carbonate sediments, Vieques, Puerto Rico. Pages 207-230 in L. J. Doyle and H. H. Roberts, eds. Carbonate-clastic transitions. Developments in Sedimentology 42. Elsevier, Amsterdam.

Davis, W. M. 1920. The islands and coral reefs of Fiji. Part II. Relation of volcanic islands to coral reefs. Geogr. J. 55 (3): 200-220.

D'Croz, L., J. B. C. Jackson, and M. M. R. Best. 1998. Siliciclastic-carbonate transitions along shelf transects through the Cayos Cochinos Archipelago, Honduras. Rev. Biol. Trop. 46 (Suppl.): 57-66.

deLange, W. P., T. R. Healy, and Y. Darlan. 1997. Reproducibility of sieve and settling tube textural determinations for sand-sized beach sediment. J. Coast. Res. 13:73-80.

Derrick, R. A. 1957. The Fiji Islands: A geographical handbook. Government Printer, Suva.

Dey, S., and L. Smith. 1989. Carbonate and volcanic sediment distribution patterns on the Grenadines Bank, Lesser Antilles Island Arc, East Caribbean. Bull. Can. Pet. Geol. 37:18-30.

Doyle, L. J., and H. H. Roberts, eds. 1988. Carbonate-clastic transitions. Developments in Sedimentology 42. Elsevier, Amsterdam.

Drew, E. A. 2001. Ocean nutrients to sediment banks via tidal jets and Halimeda meadows. Pages 255-268 in E. Wolanski, ed. Oceanographic processes of coral reefs: Physical and biological links in the Great 
Barrier Reef. CRC Press, Boca Raton, Florida.

Fay, M., D. C. P. Masalu, and A. N. N. Muzuka. 1992. Carbonate-siliciclastic transitions in surface sediments of a back-reef lagoon north of Dar es Salaam (Tanzania). Sediment. Geol. 78:49-57.

Folk, R. L. 1968. Petrology of sedimentary rocks. Hemphill Publishing Company, Austin, Texas.

Fornos, J. J., V. Forteza, C. Jaume, and A. Martinez-Taberner. 1990. A mixed carbonate/clastic example in a restricted bay in a temperate carbonate shelf (Cala Fornells, northern Minorca, Spain). Bull. Am. Assoc. Pet. Geol. 74:655-656 (abstract).

Fournier, F. 1960. Climat et erosion: La relation entre l'erosion du sol l'eau et les precipitations atmospheriques. Presses Universitaires de France, Paris.

Freile, D., and L. Hillis. 1997. Carbonate productivity by Halimeda incrassata in a land proximal lagoon, Pico Feo, San Blas, Panama. Proc. 8th Int. Coral Reef Symp., Panama 1:767-772.

Guilcher, A. 1985. Nature and human change of sedimentation in lagoons behind barrier reefs in the humid tropics. Proc. 5th Int. Coral Reef Congr., Tahiti, French Polynesia 4:207-212.

Gussmann, O. A. 1996. Oceanography and sedimentology of a tropical lagoon, southeast Viti Levu, Fiji. M. Sc. Thesis, University of Otago, Dunedin, New Zealand.

Hallock, P., and W. Schlager. 1986. Nutrient excess and the demise of coral reefs and carbonate platforms. Palaios 1:389-398.

Hands, M. R., J. R. French, and A. O'Neil. 1993. Reef stress at Cahuita Point, Costa Rica: Anthropogenically enhanced sediment influx or natural geomorphic change? J. Coast. Res. 9:11-25.

Harney, J. N., P. Hallock, C. H. Fletcher III, and B. M. Richmond. 1999. Standing crop and sediment production of reef-dwelling Foraminifera on O'ahu, Hawai'i. Pac. Sci. 53:61-73.

Harris, L. 1980. The Good Friday floods associated with cyclone Wally, 3-5 April, 1980. Public Works Department, Hydrology Section Report, Suva, Fiji.
Heap, A. D., G. R. Dickens, and L. K. Stewart. 2001. Late Holocene sediment in Nara Inlet, central Great Barrier Reef platform, Australia: Sediment accumulation on the middle shelf of a tropical mixed clastic/ carbonate system. Mar. Geol. 176:39-54.

Heikoop, J. M., and M. J. Risk. 1993. Heavy minerals as indicators of longshore drift in beach sediment at Manzanillo, Limon Province, Costal Rica. Brenesia 39-40:5158.

Heyman, W. D., and B. Kjerfve. 1999. Hydrological and oceanographic considerations for integrated coastal zone management in southern Belize. Environ. Manage. 24 (2): $229-245$.

Hillis, L. 1997. Coralgal reefs from a calcareous green alga perspective, and a first carbonate budget. Proc. 8th Int. Coral Reef Symp., Panama 1:761-766.

Hillis-Colinvaux, L. 1986. Deep-water populations of Halimeda in the economy of an atoll. Bull. Mar. Sci. 38:155-169.

Holthus, P. F. 1991. Effects of increased sedimentation on coral reef ecosystems. Pages 145-154 in Workshop on coastal processes in the South Pacific island nations, Lae, Papua New Guinea. SOPAC, Technical Bulletin 7 .

Hooke, J. M., M. J. Bray, and D. J. Carter. 1996. Sediment transport analysis as a component of coastal management-a UK example. Environ. Geol. 27:347-357.

Howorth, R., M. J. Crozier, and I. J. Grant. 1981. Effects of tropical cyclone Wally in southeast Viti Levu, Fiji, Easter 1980. Search (Syd.) 12:41-43.

Hubbard, D. K. 1990. Hurricane-induced sediment transport in open-shelf tropical systems - an example from St. Croix, U. S. Virgin Islands. J. Sediment. Petrol. 62: 946-960.

James, N. P. 1997. The cool-water carbonate depositional realm. Pages $1-20$ in $\mathrm{N}$. P. James and J. A. D. Clarke, eds. Cool-water carbonates. SEPM, Special Publication 56.

Kinsey, D. W., and D. Hopley. 1991. The significance of coral reefs as global carbon sinks-response to greenhouse. Palaeogeogr. Palaeoclimatol. Palaeoecol. (Global 
and Planetary Change Section) 89:363377.

Larcombe, P., and K. J. Woolfe. 1999. Increased sediment supply to the Great Barrier Reef will not increase sediment accumulation at most coral reefs. Coral Reefs 18:163-169.

Lees, A., and A. T. Buller. 1972. Modern temperate-water and warm-water shelf carbonate sediments contrasted. Mar. Geol. 13:M67-M73.

Li, C., B. Jones, and W. B. C. Kalbfleisch. 1998. Carbonate sediment transport pathways based on Foraminifera: Case study from Frank Sound, Grand Cayman, British West Indies. Sedimentology 45:109120.

Masse, J.-P., B. A. Thomassin, and M. Acquaviva. 1989. Bioclastic sedimentary environments of coral reefs and lagoons around Mayotte Island (Comoro Archipelago, Mozambique Channel, SW Indian Ocean). J. Coast. Res. 5:419-432.

Menard, H. W. 1983. Insular erosion, isostacy, and subsidence. Science (Washington, D.C.) 220:913-918.

Milliman, J. D. 1974. Marine carbonates. Recent sedimentary carbonates, Part 1. Springer Verlag, Berlin.

-1993. Production and accumulation of calcium carbonate in the ocean: Budget of a non-steady state. Global Biogeochem. Cycles 7:927-957.

Milliman, J. D., K. L. Farnsworth, and C. S. Albertin. 1999. Flux and fate of fluvial sediments leaving large islands in the East Indies. J. Sea Res. 41:97-107.

Mount, J. F. 1984. Mixing of siliciclastics and carbonate sediments in shallow shelf environments. Geology 12:432-435.

- 1985. Mixed siliciclastic and carbonate sediments: A proposed first-order textural and compositional classification. Sedimentology 32:435-442.

Mueller-Dombois, D. 1999. Biodiversity and environmental gradients across the tropical Pacific islands: A new strategy for research and conservation. Naturwissenschaften $86: 253-261$.

Murray, S. P., H. H. Roberts, and M. H. Young. 1983. Control of terrigenous- carbonate facies transitions by baroclinic coastal currents. Bull. Am. Assoc. Pet. Geol. 67:522-523 (abstract).

Nittrouer, C., and N. Driscoll. 1999. Source to sink. MARGINS Newsletter, No. 3: $2-3$.

Nunn, P. D. 1990. Coastal processes and landforms of Fiji: Their bearing on Holocene sea-level changes in the South and West Pacific. J. Coast. Res. 6:279-310. - 1994. Oceanic islands. Blackwell, Oxford.

Pilkey, O. H., D. M. Bush, and R. W. Rodriguez. 1988. Carbonate-terrigenous sedimentation on the North Puerto Rico shelf. Pages 231-250 in L. J. Doyle and H. II. Roberts, eds. Carbonate-clastic transitions. Developments in Sedimentology 42. Elsevier, Amsterdam.

Richmond, B. M. 1990. Aggregate resources in reef environments: Three examples from the South Pacific. AAPG (Am. Assoc. Pet. Geol.) Bull. 74:998 (abstract).

Roberts, H. H., and J. Sydow. 1997. Carbonate-siliciclastic interactions in a tropical deltaic setting: Mahakam Delta of East Kalimantan (Indonesia). Proc. 8th Int. Coral Reef Symp., Panama 2:1773-1778.

Rodda, P. 1994. Geology of Fiij. Pages 131151 in A. J. Stevenson, R. H. Herzer, and P. F. Ballance, eds. Geology and submarine resources of the Tonga-LauFiji region. SOPAC, Technical Bulletin 8.

Rogers, C. S. 1990. Responses of coral reefs and reef organisms to sedimentation. Mar. Ecol. Prog. Ser. 62:185-202.

Schneidermann, N., O. H. Pilkey, and C. Saunders. 1976. Sedimentation on the Puerto Rico insular shelf. J. Sediment. Petrol. 46:167-173.

Shepherd, M. J. 1990. The evolution of a moderate energy coast in Holocene time, Pacific Harbour, Viti Levu, Fiji. N. Z. J. Geol. Geophys. 33:547-556.

Shorten, G. G. 1993. Stratigraphy, sedimentology and engineering aspects of Holocene organo-calcareous silts, Suva Harbour, Fiji. Mar. Geol. 110:275-302.

Simone, L., and G. Carannante. 1988. The fate of foramol ("temperate-type") car- 
bonate platforms. Sediment. Geol. 60: 347-354.

Smith, R., and E. Saphore. 1987. Offshore survey techniques for a hydrogeological application, the Navua River. Fiji Mineral Resources Department Note BP35/10.

Soicher, A. J., and F. L. Peterson. 1997. Terrestrial nutrient and sediment fluxes to the coastal waters of West Maui, Hawai'i. Pac. Sci. 51:221-232.

Stark, J. E., and E. C. Dapples. 1941. Nearshore coral lagoon sediments from Raiatea,
Society Islands. J. Sediment. Petrol. 11: $21-27$.

Tomascik, T., and A. J. Mah. 1994. The ecology of 'Halimeda Lagoon': An anchialine lagoon of a raised atoll, Kakaban Island, East Kalimantan, Indonesia. Trop. Biodivers. 2:385-399.

Weiss, M. A., D. A. Goddard, and X. Picard. 1978. Marine geology of reefs and inner shelf, Chichiriviche, Estado Falcón, Venezuela. Mar. Geol. 28:211-244. 